Bangladesh J. Bot. 49(1): 55-63, 2020 (March)

\title{
ANALYSIS OF GENOTYPE-ENVIRONMENT INTERACTIONS OF SILAGE MAIZE CULTIVARS UNDER ENVIRONMENTAL TRIALS
}

\author{
Haiwang Yue, Heqin Li ${ }^{1}$, Liping Xu ${ }^{2}$, Junzhou Bu, Jianwei Wei, Shuping Chen, \\ Haicheng Peng, Junliang Xie, Shuqi Shang ${ }^{1}$ and Xuwen Jiang ${ }^{1} *$ \\ Dryland Farming Institute, Hebei Academy of Agriculture and Forestry Sciences/ Hebei \\ Provincial Key Laboratory of Crops Drought Resistance Research Hengshui, China
}

Keywords: Adaptability, AMMI model, Discriminating, GGE biplot, Representativeness

\begin{abstract}
To evaluate the adaptability and stability of silage maize cultivars and identify the representativeness and discrimination of each testing site, a two-year field research in a randomized complete block design (RCBD) with three replicates at 10 testing sites was conducted. An additive main effect and multiplicative interaction (AMMI) model and a genotype plus genotype environment interactions (GEI) biplot (referred to as GGE hereafter) were used to analyze the data. The two-year test revealed that four cultivars (Zhongdi 175 (ZD175), Qiushuo 008 (Q008), Hengyu 1587 (H1587), and Yayuqingzhu 8 (Y8) exhibited high yield and good stability, whereas two cultivars (Zhongbeiqingzhu 410 (Z410) and Fangyu 36 (F36) had low yield and poor stability. The comprehensive application of the AMMI model and the GGE biplot could accurately and intuitively evaluate the high yield, stability, and adaptability of each cultivar.
\end{abstract}

\section{Introduction}

Maize (Zea mays L.) is China's largest food crop. It is also an important feed and economic and bioenergy-producing crop. With the increasing demand for maize as food, feed, and biofuel, maize quality and yield should be improved (Yue et al. 2018). Silage maize is harvested from the whole green plant of corn and used as feed for cattle, sheep, and other herbivorous animals after chopping and lactic acid fermentation (Kusvuran et al. 2015). Silage maize is the most important component of ruminant forage and widely used in animal feed. Silage maize is favored in western countries because of its high nutritional value and biological yield. Approximately 15 million cows in China need more than 3 million ha of silage maize. However, the planting area of highquality silage maize is still insufficient (Wang et al. 2016). The adjustment of the structure of China's planting industry has changed the dual structure of grains and cash crops and gradually transformed into a ternary structure for the coordinated development of grain crops, forage, and economic crops. Silage maize is also used as the main feed for animal husbandry. Thus, silage maize sources play an important role in these sectors.

High and stable yields have been the primary concern of breeders (Mohammed et al. 2016). Yield is a complex genetic trait controlled by multiple genes, which are influenced by genotype, environment, and genotype-by-environment interaction (GEI). To screen cultivars with high and stable yields, breeders should subject new cultivars to multi-environment trials. In these trials, the high yield, stable yield, resistance, and adaptability of cultivars are assessed, and a scientific basis for cultivar promotion and utilization is provided (Caproni et al. 2018). Genotypes are placed in different environments to observe their performance. GEI is analyzed, and cultivars that are beneficial to production and social needs are selected. Thus, appropriate and accurate analysis methods should be used (Yan and Holland 2010).

"Author for correspondence: <mjxw888@163.com>. ${ }^{1}$ College of Agronomy, Qingdao Agricultural University, Qingdao, 266109, China. ${ }^{2}$ Nantong Institute of Technology Nantong, Jiangsu, China. 
Statistical methods have been developed to study GEI for cultivar stability analysis in multienvironment trials (Becker and Léon 1988). Among these methods, GEI analysis involves an additive main effect and multiplicative interaction (AMMI) model, which was first proposed by Guach. This model combines principal component (PC) analysis and variance analysis to add product - form interactions to conventional genotype and environment additive models. This model not only analyzes the significance of interactions but also estimates the characteristics and forms of interactions. It has also been widely utilized for the GEI analysis of different crops. Genotype plus genotype and environment (GGE) biplot is a new method to study GEI, crop yield stability, and plot representation. Gabriel (1971) first proposed the biplot concept. Yan (2001) subsequently developed a graphical method called a GGE biplot that can analyze multienvironment trials. This biplot consists of the first principal component axis (PC1) and the second principal component axis (PC2) formed by the single-value decomposition of genotype and GEI and by the GGE double labeling scheme. A GGE double plot method is more intuitive and clearer than other analysis methods in terms of identifying stable yields, regional adaptability of cultivars, and resolving ability of a test environment for cultivars. This method also provides a basis for screening ideal cultivars, ideal plots, and utilization value and planting layout of various cultivars (Xu et al. 2014). AMMI models and GGE biplots are successful methods used to analyze species and environment interactions. Their analysis of GEI is similar ( $\operatorname{Rad}$ et al. 2013, Mortazavian et al. 2014). In this study, an AMMI model and a GGE biplot were used to analyze genotype and environment interaction modes for silage maize cultivars from 2015 to 2016 in multi-environment trials to comprehensively evaluate the stability of the silage maize cultivars and the representativeness of the testing sites. This study aimed to provide a theoretical basis for further use and promotion of new silage cultivars in production.

\section{Materials and Methods}

The silage maize (Zea mays L.) genotypes used in this study and their supplier organizations and institutions are provided in Table 1 . Twenty three silage maize cultivars were grown in mutienvironment trials throughout two crop seasons in 2015 - 2016. Their basic information is also presented in Table 1. Experiments were conducted across 10 environments, namely Dezhou (DZ), Gaoyang (GY), Jinghai (JH), Handan (HD), Liaocheng (LC), Linfen (LF), Luoyang (LY), Suzhou (SZ), Yuncheng (YC) and Zhengzhou (ZZ). The geographic and weather characteristics of the testing sites are shown in Table 2.

The experimental design RCBD was used in this study with three replicates. The experimental plots were $6.7 \mathrm{~m}$ in length and $3.0 \mathrm{~m}$ in width. Each plot had five rows with a row-to-row distance of $60.0 \mathrm{~cm}$ and a planting density of 75,000 plants/ha. Sowing dates ranged from 15 June to 20 June at each testing site depending on the harvest time of wheat. Before sowing was conducted, $150 \mathrm{~kg} \mathrm{~N} / \mathrm{ha}, 70 \mathrm{~kg} \mathrm{P}_{2} \mathrm{O}_{5} / \mathrm{ha}$, and $70 \mathrm{~kg} \mathrm{~K} \mathrm{~K}_{2} \mathrm{O} / \mathrm{ha}$ were added to the soil. Weeding work was carried out twice, that is, before the seedlings sprouted and at the three-leaf stages. All of the silage maize cultivars were harvested at the milk-dough stage, and three lines in the middle of each plot were harvested manually. All of the agricultural operations during the trial were based on local field production.

ANOVA was conducted to detect the differences between cultivars, environments, and cultivars and environments. Microsoft Excel version 2007 (Microsoft Corporation) was used for data processing. GEI was examined using the AMMI model and the GGE biplot embedded in GenStat (Genstat, $18^{\text {th }}$ edition):

(1) GGE model: $Y_{\mathrm{ij}}-\mu-\beta_{\mathrm{j}}=\mathrm{a}_{\mathrm{i}}+\mathrm{j}_{\mathrm{ij}} \ldots$

(2) AMMI model: $\mathrm{Y}_{\mathrm{ij}}-\mu-\beta_{\mathrm{j}}-\mathrm{a}_{\mathrm{i}}=\mathrm{j}_{\mathrm{ij}} \ldots$ 
where $Y_{i j}$ represents the measured mean of the ith genotype in the jth environment, $\mu$ represents the grand mean, $a_{\mathrm{i}}$ represents the main effect of the ith genotype, $\beta_{\mathrm{j}}$ represents the main effect of the $\mathrm{jth}$ environment, $\mathrm{j}_{\mathrm{ij}}$ represents the interaction between ith genotype and $\mathrm{j}$ environment (Nzuve et al. 2013).

Table 1. Basic information of the cultivars and its code used in experiment.

\begin{tabular}{|c|c|c|c|c|}
\hline Cultivar & Code & Plant type & Breeding institute & Year \\
\hline Zhaoyu 27 & $\mathrm{Z} 27$ & Flat & Hebei Zhaoyu Seed Industry Co., Ltd. & 2015 \\
\hline Hengyu 1587 & H1587 & Semi-compact & $\begin{array}{l}\text { Dryland Farming Institute, Hebei Academy } \\
\text { of Agriculture and Forestry Sciences }\end{array}$ & $2015-16$ \\
\hline Yuqingzhu 23 & Y23 & Flat & Henan Dajingjiu Seed Industry CO., Ltd. & 2015 \\
\hline Zhongbeiqingzhu 410 & $\mathrm{Z} 410$ & $"$ & Northern Shanxi Seed Industry CO., Ltd. & 2015 \\
\hline Zhongdi 175 & $\mathrm{Z} 175$ & Semi-compact & $\begin{array}{l}\text { Dryland Farming Institute, Hebei Academy } \\
\text { of Agriculture and Forestry Sciences }\end{array}$ & $2015-16$ \\
\hline Nongda 108 & N108 & Flat & China Agricultural University & 2015 \\
\hline Hongruiqingzhu 101 & H101 & $"$ & Hongrui Seed Industry Co., Ltd. & $2015-16$ \\
\hline Heyu 36 & H36 & $"$ & $\begin{array}{l}\text { Beijing Zhongnong Sanhe Agricultural } \\
\text { Technology Co., Ltd. }\end{array}$ & $2015-16$ \\
\hline Zhaoyu 3318 & $\mathrm{Z} 3318$ & $"$ & Hebei Zhaoyu Seed Industry Co., Ltd. & $2015-16$ \\
\hline Zhengdan 958 & Z958 & Semi-compact & $\begin{array}{l}\text { Henan Academy of Agriculture and Forestry } \\
\text { Sciences }\end{array}$ & 2015 \\
\hline Wangheqingzhu 1 & W1 & Semi-compact & $\begin{array}{l}\text { Beijing Guangyuan Wanghao Seed Industry } \\
\text { Co., Ltd. }\end{array}$ & 2015 \\
\hline Qingzhuxunqing 518 & Q518 & Flat & $\begin{array}{l}\text { Xuanhua Xuntian New Technology Seed } \\
\text { Industry Co., Ltd. }\end{array}$ & 2015 \\
\hline Huaiyanqingzhu 6 & H6 & $"$ & $\begin{array}{l}\text { Beijing Wannong Seed Research Institute } \\
\text { Co., Ltd. }\end{array}$ & 2015 \\
\hline Qiushuo 008 & Q008 & $"$ & Hebei Qiushuo Seed Industry Co., Ltd. & 2015-16 \\
\hline Yayuqingzhu 8 & Y8 & $"$ & $\begin{array}{l}\text { Sichuan Yayu Technology Development Co., } \\
\text { Ltd. }\end{array}$ & $2015-16$ \\
\hline Jiashi 14006 & $\mathrm{~J} 14006$ & Semi-compact & Jiahe Seed Industry Co., Ltd. & 2016 \\
\hline Nongfengqingzhu 166 & N166 & Semi-compact & $\begin{array}{l}\text { Beijing Wannong Pioneer Biotechnology } \\
\text { Co., Ltd. }\end{array}$ & 2016 \\
\hline Qingzhuxunqing 938 & Q938 & Flat & $\begin{array}{l}\text { Xuanhua Xuntian New Technology Seed } \\
\text { Industry Co., Ltd. }\end{array}$ & 2016 \\
\hline Zhuqing 1 & $\mathrm{Z} 1$ & Semi-compact & $\begin{array}{l}\text { Guiyang Agricultural Machinery Promotion } \\
\text { Center }\end{array}$ & 2016 \\
\hline Fangyu 36 & F36 & Flat & Hebei Dehua Seed Industry Co., Ltd. & 2016 \\
\hline Xianyu 1321 & $\mathrm{X} 1321$ & $"$ & Pioneer Seed Co. & 2016 \\
\hline Xianyu 1581 & $\mathrm{X} 1581$ & $"$ & Pioneer Seed Co. & 2016 \\
\hline Jinzhu 100 & $\mathrm{~J} 100$ & Semi-compact & Tianjin Zhongtian Dadi Technology Co., Ltd. & 2016 \\
\hline
\end{tabular}


Table 2. Description of the testing site for the evaluation of silage maize cultivars in 2015 - 16.

\begin{tabular}{llcccccc}
\hline $\begin{array}{l}\text { Testing } \\
\text { site }\end{array}$ & Province & Code & $\begin{array}{c}\text { Longitude } \\
(\mathrm{E})\end{array}$ & $\begin{array}{c}\text { Latitude } \\
(\mathrm{N})\end{array}$ & $\begin{array}{c}\text { Altitude } \\
(\mathrm{m})\end{array}$ & $\begin{array}{c}\text { Annual rainfall } \\
(\mathrm{mm})\end{array}$ & $\begin{array}{c}\text { Mean annual } \\
\text { temp. }\left({ }^{\circ} \mathrm{C}\right)\end{array}$ \\
\hline Dezhou & Shandong & $\mathrm{DZ}$ & $116^{\circ} 27^{\prime}$ & $37^{\circ} 28^{\prime}$ & 22 & 547 & 13.1 \\
Gaoyang & Hebei & $\mathrm{GY}$ & $115^{\circ} 78^{\prime}$ & $38^{\circ} 69^{\prime}$ & 14 & 312 & 12.5 \\
Jinghai & Tianjin & $\mathrm{JH}$ & $116^{\circ} 98^{\prime}$ & $38^{\circ} 95^{\prime}$ & 6 & 686 & 13.9 \\
Handan & Hebei & $\mathrm{HD}$ & $114^{\circ} 53^{\prime}$ & $36^{\circ} 64^{\prime}$ & 55 & 424 & 14.6 \\
Liaocheng & Shandong & $\mathrm{LC}$ & $115^{\circ} 98^{\prime}$ & $36^{\circ} 45^{\prime}$ & 37 & 543 & 13.6 \\
Linfen & Shanxi & $\mathrm{LF}$ & $115^{\circ} 50^{\prime}$ & $36^{\circ} 05^{\prime}$ & 450 & 478 & 12.2 \\
Luoyang & Henan & $\mathrm{LY}$ & $112^{\circ} 43^{\prime}$ & $34^{\circ} 62^{\prime}$ & 138 & 485 & 15.1 \\
Suzhou & Anhui & $\mathrm{SZ}$ & $116^{\circ} 94^{\prime}$ & $33^{\circ} 63^{\prime}$ & 28 & 825 & 16.2 \\
Yuncheng & Shanxi & $\mathrm{YC}$ & $111^{\circ} 01^{\prime}$ & $35^{\circ} 02^{\prime}$ & 369 & 502 & 14.3 \\
Zhengzhou & Henan & $\mathrm{ZZ}$ & $113^{\circ} 62^{\prime}$ & $34^{\circ} 73^{\prime}$ & 110 & 537 & 15.7 \\
\hline
\end{tabular}

\section{Results and Discussion}

ANOVA showed that genotypes, environments, and GEI significantly affected the silage biomass yield in 2015 ( $p<0.01$ ). Environments accounted for $42.53 \%$ of the sum of squares (SS), and genotypes and GEI corresponded to 19.07 and $18.47 \%$ of the SS, respectively (Table 3). Among the three influencing factors, environments had the greatest influence on the stability of the tested cultivars, indicating that the tested cultivars significantly differed (Kendal et al. 2016, Amare and Adisu 2017). Therefore, different environmental conditions can be used as a basis for selecting appropriate cultivars (Abakemal et al. 2016). GEI plays an important role in the stability of the tested cultivars (Kandus et al. 2010). However, the stability of the cultivars was analyzed because the variation in environments accounted for the majority.

The regression analysis of the silage maize yields (Table 3) revealed that the combination of joint regression, genetic regression, and environmental regression accounted for $28.58 \%$ of the total SS. The residual was still large, accounting for $71.42 \%$, and joint regression, genetic regression, environmental regression, and residual were extremely significant $(\mathrm{p}<0.01)$. These results indicated that the regression model showed low interaction and had poor results after the experimental data were fitted.

ANOVA revealed that the effects of genotypes, environments, GEI in 2016 were significant, and SS explained $38.16 \%$ for environmental effects, $11.48 \%$ for environmental effects, and $27.31 \%$ for GEI effects. Linear regression analysis indicated that the sum of joint regression, gene regression, and environmental regression accounted for $35.19 \%$ of the interaction, and the residual accounted for $64.81 \%$. These values reached extremely significant levels $(\mathrm{p}<0.01)$. The AMMI model results suggested that all of the interaction principal component axes (IPCAs) accounted for $76.81 \%$ of the interaction, and the residual was $23.19 \%$ (Table 4).

The GEI effect was further divided into IPCAs, namely IPCA1, IPCA2, IPCA3, and residual effects. All IPCAs reached a significant level and accounted for 40.51, 21.67 and $13.56 \%$ of the GEI variation. The residuals corresponded to $24.25 \%$ (Table 3); that is, the total interactions of the first three items accounted for $75.74 \%$. The AMMI model could be used to thoroughly analyze GEI interaction information, and the AMMI model was significantly better than traditional regression models. Therefore, the AMMI model could effectively overcome the limitations of linear regression analysis in evaluating the stability of plant genotypes (Oyekunle et al. 2017). 
Table 3. Analysis of variance, linear regression analysis and AMMI model analysis in 2015.

\begin{tabular}{llllllll}
\hline Methods & $\begin{array}{l}\text { Source of } \\
\text { variance }\end{array}$ & $\begin{array}{l}\text { Degree of } \\
\text { freedom }\end{array}$ & $\begin{array}{l}\text { Sum of } \\
\text { squares }\end{array}$ & $\begin{array}{l}\text { Mean } \\
\text { squares }\end{array}$ & $\begin{array}{l}\text { \%/total } \\
\text { SS }\end{array}$ & $\begin{array}{l}\text { \%/SS of } \\
\text { interaction }\end{array}$ & $\begin{array}{l}\text { F } \\
\text { value }\end{array}$ \\
\hline AOVA & Total variance & 449 & 20279109.69 & 45165.06 & - & - & \\
& Treatment & 149 & 16237081.48 & 108973.70 & - & - & $8.09^{* *}$ \\
& Genotype & 14 & 3867765.72 & 276268.98 & 19.07 & - & $20.50^{* *}$ \\
& Environment & 9 & 8623226.89 & 958136.32 & 42.53 & - & $71.11^{* *}$ \\
& Genotype and & 126 & 3746088.87 & 29730.86 & 18.47 & - & $2.21^{* *}$ \\
& environment & & & & & & \\
& interaction & & & & & & - \\
& Error & 300 & 4042028.21 & 13473.43 & 19.93 & - & $7.54^{* *}$ \\
Linear & Joint regression & 1 & 101545.73 & 101545.73 & - & 2.71 & $3.72^{* *}$ \\
analysis & Genetic & 13 & 651138.06 & 50087.54 & - & 17.38 & \\
& regression & & & & & & $2.95^{* *}$ \\
& Environmental & 8 & 318101.01 & 39762.63 & - & 8.49 & \\
& regression & & & & & & \\
& Residual & 104 & 2675304.06 & 25724.08 & - & 71.42 & $1.91^{* *}$ \\
AMMI & IPCA1 & 22 & 1517548.74 & 68979.49 & - & 40.51 & $5.01^{* *}$ \\
model & IPCA2 & 20 & 811964.29 & 40598.21 & - & 21.67 & $2.95^{* *}$ \\
& IPCA3 & 18 & 508020.67 & 28223.37 & - & 13.56 & $2.05^{* *}$ \\
& Residual & 66 & 908555.18 & 13765.99 & - & 24.25 & \\
\hline
\end{tabular}

- Mean not existed, ${ }^{* *}$ Mean significant at $1 \%$ probability level.

Table 4. Analysis of variance, linear regression analysis and AMMI model analysis in 2016.

\begin{tabular}{|c|c|c|c|c|c|c|c|}
\hline Methods & $\begin{array}{l}\text { Source of } \\
\text { variance }\end{array}$ & $\begin{array}{l}\text { Degree of } \\
\text { freedom }\end{array}$ & $\begin{array}{l}\text { Sum of } \\
\text { squares }\end{array}$ & $\begin{array}{l}\text { Mean } \\
\text { squares }\end{array}$ & $\begin{array}{l}\% / \text { total } \\
\text { SS }\end{array}$ & $\begin{array}{l}\% / \mathrm{SS} \text { of } \\
\text { interaction }\end{array}$ & $\begin{array}{l}\mathrm{F} \\
\text { value }\end{array}$ \\
\hline \multirow[t]{6}{*}{ AOVA } & Total variance & 449 & 26125271.79 & 58185.46 & - & - & \\
\hline & Treatment & 149 & 20105696.21 & 134937.56 & - & - & $6.72^{* *}$ \\
\hline & Genotype & 14 & 3000971.379 & 214355.09 & 11.48 & - & $10.68^{* * *}$ \\
\hline & Environment & 9 & 9969864.35 & 1107762.70 & 38.16 & - & $55.21^{* * *}$ \\
\hline & $\begin{array}{l}\text { Genotype and } \\
\text { environment } \\
\text { interaction }\end{array}$ & 126 & 7134860.48 & 56625.88 & 27.31 & - & $2.82^{* *}$ \\
\hline & Error & 300 & 6019575.58 & 20065.25 & 23.04 & - & - \\
\hline \multirow{4}{*}{$\begin{array}{l}\text { Linear } \\
\text { regression } \\
\text { analysis }\end{array}$} & Joint regression & 1 & 3877.81 & 3877.81 & - & 0.05 & 0.19 \\
\hline & $\begin{array}{l}\text { Genetic } \\
\text { regression }\end{array}$ & 13 & 1380416.19 & 106185.86 & - & 19.35 & 5.29 \\
\hline & $\begin{array}{l}\text { Environmental } \\
\text { regression }\end{array}$ & 8 & 1126790.88 & 140848.86 & - & 15.79 & 7.01 \\
\hline & Residual & 104 & 4623775.58 & 44459.38 & - & 64.81 & 2.21 \\
\hline \multirow{4}{*}{$\begin{array}{l}\text { AMMI } \\
\text { model }\end{array}$} & IPCA1 & 22 & 2456853.42 & 111675.15 & - & 34.43 & 4.45 \\
\hline & IPCA2 & 20 & 1685117.44 & 84255.87 & - & 23.62 & 3.36 \\
\hline & IPCA3 & 18 & 1338608.91 & 74367.16 & - & 18.76 & 2.96 \\
\hline & Residual & 66 & 1654280.69 & 25064.85 & - & 23.19 & \\
\hline
\end{tabular}

- and ${ }^{* *}$ same as in Table 3. 
The cultivars located farthest from the origin in the same direction were connected to form a polygon, and all of the other cultivars were placed inside the polygon. From the origin $(0,0)$, the sides of the polygon were perpendicular. These vertical lines cut the entire double graph into multiple sectors, thereby dividing the test points into different groups. The cultivar located in the top corner position of each sector showed the highest yield in the region in each environment. The cultivars inside the polygon and close to the origin were close to the average yield and were insensitive to environmental changes (Sharma et al. 2010).

The PC1 of the yield traits of silage maize in the multipoint identification trial in 2015 accounted for $56.79 \%$ of genotype + GE, whereas PC2 corresponded to $19.69 \%$ genotype + GE. The GGE double biplot could explain $76.47 \%$ of the G + GE interactions (PC1 + PC2) (Fig. 1). Z27, N108, Z410, Z958, H36 and Z175 were at the top of the polygon, respectively, indicating that these cultivars performed the best in their area. H101 had the highest yield in LF and SZ pilots. Z175 had the highest output in ZZ, DZ, LC, HD and JH. H36 had the highest yield in GY; Z958, Z410, N108, and Z27 did not have plots, thereby indicating that these cultivars did not perform well in all of the testing sites.
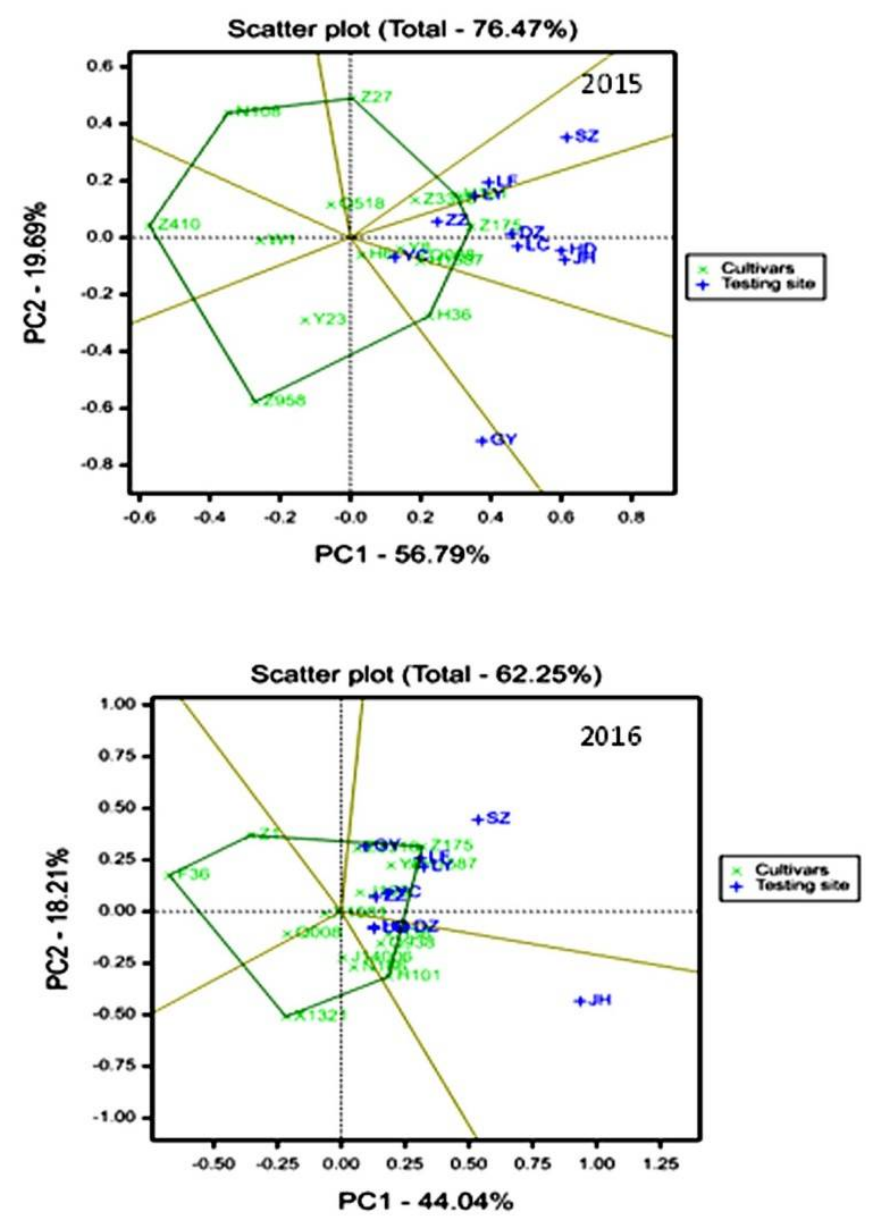

Fig. 1. Adaptability of silage maize cultivars for biomass yield based on GGE-biplot analysis. 
The first two principal components (PC1 + PC2) explained 62.25\% of genotype + GE in 2016 (PC1 44.04\% and PC2 18.21\%) (Fig. 1). Z175, H101, X1321, F36 and Z1 were located at the top of the polygon that was divided into four sectors. The plots in the first sector were SZ, GY, LF, LY, $\mathrm{ZZ}$ and YC. Among them, Z175 had the best performance in the first sector, thereby suggesting that Z175 had good adaptability, and the biomass yield was high in these plots. The plots in the second sector were JH, DZ, LC and HD; H101 showed the best performance in the testing sites. X1321, F36 and Z1 did not have plots in the sector, thereby indicating that these cultivars performed poorly in all the plot sites.
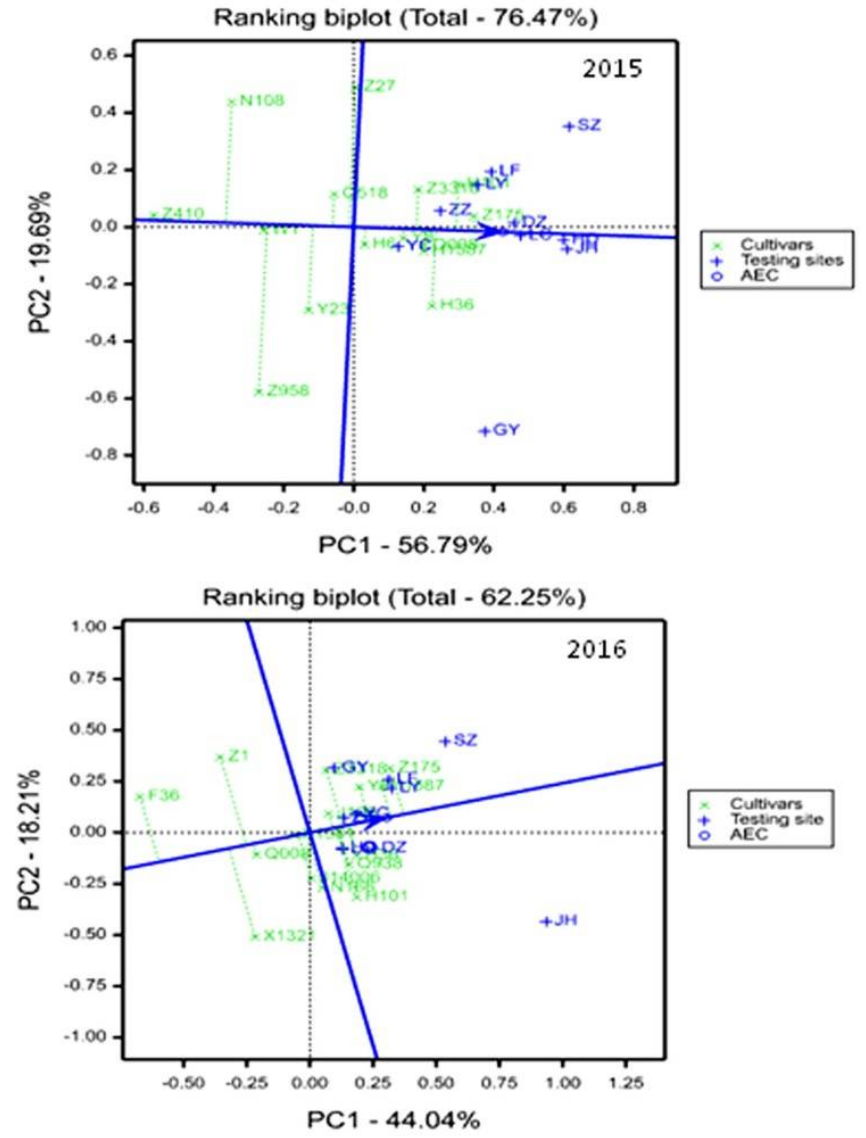

Fig. 2. Analysis of high yield and stable yield of silage maize cultivars.

The comprehensive analysis of the two-year data revealed that the performance and adaptability of Z175 and H101 were better than those of the other cultivars. The biomass yields of Z958, Z410, N108, Z27, X1321, F36 and Z1 were relatively low in all of the testing sites.

In Fig. 2, the straight line with an arrow was the average environmental coordinate (AEC) axis, the circle on the straight line was the average environmental value, and the straight line passing through the center and the average environmental axis. A vertical line was made between the cultivar point and the AEC for the analysis of the yield and stability of the tested cultivars. The direction of the AEC was the trend of the approximate average yield of the cultivar under all of the circumstances (Mehari et al. 2015). 
In the multi-environment trial in 2015, the highest average biomass yield was observed in Z175, followed by H101, H36, H1587, Q008, Z3318, Y8, H6, Z27, Q518, Y23, Z958, W1, N108 and Z410. Passing the center (origin), the line perpendicular to the average axis represented the tendency of each cultivar to interact with each environment. The longer the vertical line between the cultivars and the AEC was, the more unstable the cultivars would be (Lakew et al. 2014). The most unstable cultivar was Z958, followed by Z27 and N108. The stability of Z410, Y8, Z175, H6 and $\mathrm{H} 1587$ was good.

In the multi-environment trial in 2016, the highest average biomass yield was found in Z175, followed by H1587, Y8 and H36. By contrast, the average yield of F36 was the lowest. In terms of the stability of cultivars, Q008, J100, Y8, H1587 and Z175 were more stable than the other cultivars. Combined with identification test for two years, Z175 and H1587 had high and stable yields. Z410, Q008, H6 and Y8 had good stability and poor biomass yield. N108, Z958, X1321, $\mathrm{Z} 1$ and F36 had low yield and poor stability.

\section{Acknowledgements}

This research was supported by Special Fund for the National Natural Science Foundation of China (31601386); National System (Maize) of Modern Industrial Technology (nycytx-02); Appropriate Mechanization of New Summer Maize Variety Breeding, Demonstration and Promotion in North Huanghuaihai (Beijing-Tianjin-Hebei) (2017YFD0101202); Science and Technology Support Program of Hebei Province (16226323D-X); Shandong Key Research and Development Plan (Public Welfare Special Project, 2017GNC11103), the National Key Research and Development Program of China (2017YFD0701203), A Project of Shandong Province Higher Educational Science and Technology Program (J18KA121).

\section{References}

Abakemal D, Shimelis H and Derera J 2016. Genotype-by-environment interaction and yield stability of quality protein maize hybrids developed from tropical high land adapted inbred lines. Euphytica 209(3): 757-769.

Amare KB and Adisu G 2017. Adaptability and stability analysis of groundnut genotypes using AMMI model and GGE-biplot. J. Crop Sci. Biotechnol. 20(5): 343-349.

Becker HC and Léon L 1988. Stability analysis in plant breeding. Plant Breeding 101(1): 1-23.

Caproni L, Raggi L, Tissi C, Howlett S, Torricelli R and Negri V 2018. Multi-environment evaluation and genetic characterisation of common bean breeding lines for organic farming systems. Sustainability 10(3): 777.

Gabriel KR 1971. The biplot graphic display of matrices with application to principal component analysis. Biometrika 58(3): 453-467.

Kandus M, Almora D, Ronceros RB and Salenro JC 2010. Statistical models for evaluating the genotypeenvironment interaction in maize (Zea mays L.). Phyton. 79(1): 39-46.

Kendal E and Tekdal S 2016. Application of AMMI model for evaulation spring barley genotypes in multienvironment trials. Bangl. J. Bot. 45(3): 613-620.

Kusvuran A, Kaplan M, Nazli RI, Saruhan V and Karadag Y. 2015. Determination of possibilities to grow some corn (Zea mays L.) cultivars for silage production under Middle Kizilirmak Basin ecological conditions. J. Agr. Faculty Gaziosmanpasa Univ. 32(1): 57-67.

Lakew T, Tariku S, Alem T and Bitew M 2014. Agronomic performances and stability analysis of upland rice genotypes in North West Ethiopia. Int. J. Sci. Res. Publ. 4(4): 1-9. 
Mehari M, Tesfay M, Yirga H, Mesele A, Abebe T, Workineh A and Amare B 2015. GGE biplot analysis of genotype-by-environment interaction and grain yield stability of bread wheat genotypes in South Tigray, Ethiopia. Commun. Biometry Crop Sci. 10(1): 17-26.

Mortazavian SMM, Nikkhah HR, Hassani FA, Sharif-al-Hosseini M, Taheri M and Mahlooji M 2014. GGE biplot and AMMI analysis of yield performance of barley genotypes across different environments in Iran. J. Agr. Sci. Tech. 16(3): 609-622.

Mohammed YA, Che CC, McPhee K, Miller P, Mcvay K, Eckhoff J, Lamb P, Miller J, Khand Q, Bohannong B, Knox M and Holmes J 2016. Yield performance and stability of dry pea and lentil genotypes in semiarid cereal dominated cropping systems. Field Crops Res. 188: 31-40.

Nzuve F, Githiri S, Mukunya DM and Gethi J 2013. Analysis of genotype $\times$ environment interaction for grain yield in maize hybrids. J. Agr. Sci. 5(11): 75-85.

Oyekunle M, Haruna A, Badu-Apraku B, Usman ISS, Mani H, Ado S, Olaoye G, Obeng-Antwi K, Abdulmalik R and Ahmed H 2017. Assessment of early-maturing maize hybrids and testing sites using GGE biplot analysis. Crop Sci. 57(6): 1-9.

Rad MRN, Kadir MA, Rafii MY, Jaafar HZE, Nahavi MR and Ahmadi F 2013. Genotype $\times$ environment interaction by AMMI and GGE biplot analysis in three consecutive generations of wheat (Triticum aestivum) under normal and drought stress conditions. Aust. J. Crop Sci. 7(7): 956-961.

Sharma RC, Morgounov AI, Braun HJ, Akin B, Keser M, Bedoshvili D, Bagci A, Martius C and Ginkel M 2010. Identifying high yielding stable winter wheat genotypes for irrigated environments in Central and West Asia. Euphytica. 171(1): 53-64.

Wang HL, Ning TT, Wei H, Zheng ML and Xu CC 2016. Dynamics associated with prolonged ensiling and aerobic deterioration of total mixed ration silage containing whole crop corn. Asian Austral. J. Anim. 29(1): 62-72.

Xu NY, Fok M, Zhang GW, Li J and Zhou ZG 2014. The application of GGE biplot analysis for evaluating test locations and mega-environment investigation of cotton regional trials. J. Integr. Agr. 13(9): 19211933.

Yan WK 2001. GGE biplot-A windows application for graphical analysis of multienvironment trial data and other types of two-way data. Agron J. 93(5): 1111-1118.

Yan WK and Holland JB 2010. A heritability-adjusted GGE biplot for test environment evaluation. Euphytica. 171(3): 355-369.

Yue HW, Bu JZ, Wei JW, Chen SP, Peng HC, Xie JX, Zheng SH, Xie JL and Jiang XW 2018. Effect of planting density on grain-filling and mechanized harvest grain characteristics of summer maize varieties in Huang-Huai-Hai plain. Int. J. Agric. Biol. 20(6): 1365-1374. 